\title{
Control of Synaptic Connection by Glutamate Receptor $\delta 2$ in the Adult Cerebellum
}

\author{
Tomonori Takeuchi, ${ }^{1 *}$ Taisuke Miyazaki, ${ }^{2 *}$ Masahiko Watanabe, ${ }^{2}$ Hisashi Mori, ${ }^{1}$ Kenji Sakimura, ${ }^{3}$ and \\ Masayoshi Mishina ${ }^{1}$ \\ ${ }^{1}$ Department of Molecular Neurobiology and Pharmacology, Graduate School of Medicine, University of Tokyo, and Solution Oriented Research for Science \\ and Technology, Japan Science and Technology Agency, Tokyo 113-0033, Japan, ${ }^{2}$ Department of Anatomy, Hokkaido University School of Medicine, \\ Sapporo 060-8638, Japan, and ${ }^{3}$ Department of Cellular Neurobiology, Brain Research Institute, Niigata University, Niigata 951-8585, Japan
}

Precise topological matching of presynaptic and postsynaptic specializations is essential for efficient synaptic transmission. Furthermore, synaptic connections are subjected to rearrangements throughout life. Here we examined the role of glutamate receptor (GluR) $\delta 2$ in the adult brain by inducible and cerebellar Purkinje cell (PC)-specific gene targeting under the pure C57BL/6 genetic background. Concomitant with the decrease of postsynaptic GluR $\delta 2$ proteins, presynaptic active zones shrank progressively and postsynaptic density (PSD) expanded, resulting in mismatching between presynaptic and postsynaptic specializations at parallel fiber-PC synapses. Furthermore, GluR $\delta 2$ and PSD-93 proteins were concentrated at the contacted portion of mismatched synapses, whereas AMPA receptors were distributed in both the contacted and dissociated portions. When GluR $\delta 2$ proteins were diminished, PC spines lost their synaptic contacts. We thus identified postsynaptic GluR $\delta 2$ as a key regulator of the presynaptic active zone and PSD organization at parallel fiber-PC synapses in the adult brain.

Key words: cerebellar Purkinje cell; conditional gene targeting; glutamate receptor $\delta 2$; postsynaptic density; synaptic connection; synaptic matching

\section{Introduction}

Brain function is based on highly complex neural networks and their dynamics. Efficient synaptic transmission requires elaborate structural specializations in both presynaptic and postsynaptic cells and precise topological matching of presynaptic transmitter release machineries and postsynaptic neurotransmitter receptor complexes. Furthermore, changes in spine morphology and number after learning are observed in several brain regions, including the cerebellum (Bailey and Kandel, 1993; Lamprecht and LeDoux, 2004). Although molecular understanding of synapse formation during development is emerging (Hering and Sheng, 2001; Goda and Davis, 2003; Scheiffele, 2003), the molecular mechanism for regulation of synaptic connections in the adult brain remains to be investigated.

The $\delta$ subfamily of glutamate receptor (GluR) was found by molecular cloning (Yamazaki et al., 1992), and it positions in

Received Nov. 19, 2004; revised Jan. 11, 2005; accepted Jan. 12, 2005.

This work was supported in part by research grants from the Ministry of Education, Culture, Sports, Science, and Technology of Japan and the Japan Science and Technology Agency. We thank R. Natsume for chimeric mouse preparation, C. Stewart for ES cells, T. Yagi for plasmid pMC1DTpA, T. Ogura, K. Yoshitake, and T. Yamaguchi for help in mouse breeding, and Y. Nakajima for help in the preparation of this manuscript. We are grateful to M. Ohtsuka for his encouragement and support.

*T.T. and T.M. contributed equally to this work.

Correspondence should be addressed to Masayoshi Mishina, Department of MolecularNeurobiology and Pharmacology, Graduate School of Medicine, University of Tokyo, Tokyo 113-0033, Japan. E-mail: mishina@m.u-tokyo.ac.jp.

H. Mori's present address: Department of Molecular Neuroscience, Graduate School of Medicine, Toyama Medical and Pharmaceutical University, Toyama 930-0194, Japan.

DOI:10.1523/JNEUROSCI.4740-04.2005

Copyright $\odot 2005$ Society for Neuroscience $\quad$ 0270-6474/05/252146-11\$15.00/0 between the classical AMPA-kainate and NMDA subtypes from the amino acid sequence identity. GluR $\delta 2$, the second member of this subfamily, is selectively expressed in cerebellar Purkinje cells (PCs) (Araki et al., 1993; Lomeli et al., 1993), and within PCs, GluR $\delta 2$ proteins are localized exclusively at parallel fiber (PF)-PC synapses (Takayama et al., 1996; Landsend et al., 1997). Our previous studies showed that mutant mice lacking GluR $\delta 2$ are defective in long-term depression at PF-PC synapses, motor learning, and motor coordination (Funabiki et al., 1995; Kashiwabuchi et al., 1995; Kishimoto et al., 2001; Mishina, 2003). In addition, the number of PF-PC synapses decreased and innervation of PCs by multiple climbing fibers was sustained in GluR $\delta 2$ mutant mice (Kashiwabuchi et al., 1995; Kurihara et al., 1997; Hashimoto et al., 2001; Lalouette et al., 2001; Ichikawa et al., 2002). These studies revealed that in cerebellar PCs, in which functional NMDA receptors are absent, GluR $\delta 2$ plays a central role in synaptic plasticity, motor learning, and cerebellar wiring. However, the primary role of GluR $\delta 2$ and whether GluR $\delta 2$ regulates synaptic connections in the adult brain or only during development remained to be investigated. The NMDA receptor also plays important roles both in learning and memory (Martin et al., 2000) and in neural network formation during development (Goodman and Shatz, 1993). Furthermore, activation of NMDA receptors induces structural alterations of spines of cultured hippocampal neurons (Engert and Bonhoeffer, 1999; Maletic-Savatic et al., 1999). On the other hand, ablation of NMDA receptors in the adult brain exerted no detectable effects on synaptic structures (Tsien et al., 1996; Rampon et al., 2000). 
Thus, it is crucial to determine whether the diverse functional roles of GluR $\delta 2$ revealed by studies of conventional knock-out mice, especially regulation of cerebellar wiring, are specific for the developmental stage, although we suggested a close relationship in the molecular mechanism between synaptic plasticity at the adult stage and synapse formation during development in the cerebellum (Kashiwabuchi et al., 1995). To address this issue, we generated a target mouse line carrying the $G l u R \delta 2$ gene flanked by loxP sequences using embryonic stem (ES) cells derived from the C57BL/6 strain. Crossing the target mouse with a Cre mouse line carrying the Cre recombinase-progesterone receptor fusion protein (CrePR) gene under the control of the GluR $\delta 2$ gene promoter enabled us to inductively abolish GluR $\delta 2$ proteins selectively in cerebellar PCs of the mature brain. Here we report the effects of inducible ablation of GluR $\delta 2$ proteins on the structures of PF-PC synapses in the adult cerebellum.

\section{Materials and Methods}

Generation of mice. We isolated a mouse genomic clone carrying exon 12 of the GluR $\delta 2$ gene by screening a bacterial artificial chromosome library prepared from the C57BL/6 strain (Incyte Genomics, St. Louis, MO) using a mouse GluR $\delta 2$ cDNA encoding putative transmembrane segments M1-M3 as a probe. The $7.9 \mathrm{~kb} B a m \mathrm{HI}$ fragment from the genomic clone was subcloned into the BamHI site of pBluescript II KS(+) (Stratagene, La Jolla, CA) to yield pGRD2B1. The $1.8 \mathrm{~kb}$ DNA fragment carrying the $34 \mathrm{bp}$ loxP sequence and $P g k-1$ promoter-driven neomycin phosphotransferase gene (neo) flanked by two Flp recognition target ( $\mathrm{frt}$ ) sites was inserted into the HincII site 381 bp upstream of exon 12, and the 34 bp loxP sequence with $10 \mathrm{bp}$ linker sequences into the HindIII site $122 \mathrm{bp}$ downstream of exon 12. The targeting vector PTVD2V4 contained exon 12 of the $G l u R \delta 2$ gene flanked by loxP sequences, the $9.9 \mathrm{~kb}$ upstream and $2.3 \mathrm{~kb}$ downstream genomic sequences, and $4.3 \mathrm{~kb}$ pMC1DTpA (Taniguchi et al., 1997).

We isolated a subclone of ES cells derived from the C57BL/6 strain (Köntgen et al., 1993). ES cells were cultured on mitomycin C-treated neomycin-resistant fibroblasts in knock-out DMEM supplemented with 17.9\% knock-out serum replacement (Invitrogen, Carlsbad, CA), 90.7 $\mu \mathrm{M}$ nonessential amino acids, $1 \mathrm{~mm}$ L-glutamine, $100 \mu \mathrm{M}$ 2-mercaptoethanol, and $1 \times 10^{3} \mathrm{U} / \mathrm{ml}$ leukemia inhibitory factor (Chemicon International, Temecula, CA) at $37^{\circ} \mathrm{C}$ under humidified atmosphere containing $5 \% \mathrm{CO}_{2}$. The targeting vector was linearized by NotI and electroporated into ES cells using Gene Pulser (Bio-Rad, Hercules, CA) $(250 \mathrm{~V}, 960 \mu \mathrm{F}, r=\infty)$. G-418 selection $(150 \mu \mathrm{g} / \mathrm{ml})$ was started 36-48 h after electroporation and continued for 1 week. Recombinant clones were identified by Southern blot hybridization analysis of ScaI- or NheI-digested genomic DNA using the $0.6 \mathrm{~kb} E c 081 \mathrm{I}-M$ scI fragment from pGRD2B1, the $0.6 \mathrm{~kb}$ PstI fragment from pLFNeo (Takeuchi et al., 2002), and the $4.0 \mathrm{~kb}$ HindII-NheI fragment from pD2-9 (Kashiwabuchi et al., 1995) as 5', neo, and 3' probes, respectively. Recombinant ES cells were injected into eight-cell stage embryos of ICR mice. The embryos were cultured to blastocysts and transferred to the pseudopregnant ICR uterus.

Resulting chimeric mice were mated to FLP66 transgenic mice of the C57BL/6 strain (Takeuchi et al., 2002), and male offspring were further crossed with C57BL/6 mice. Elimination of the neo gene from the genome through Flp/frt-mediated excision was identified by Southern blot hybridization analysis with a $3^{\prime}$ probe. GluR $\delta 2^{+/ f l o x}$ mice were crossed with $G l u R \delta 2^{+/ C r e P R}$ mice (Kitayama et al., 2001) to yield GluR $\delta 2^{\text {flox/CrePR }}$ mice. Littermates derived from crossing of GluR $\delta 2^{\text {flox/flox }}$ and $G l u R \delta 2^{\text {flox/ }}$ $C r e P R$ mice with the pure C57BL/6 genetic background were used for subsequent studies. Animal care was performed in accordance with institutional guidelines. Mice were fed ad libitum with standard laboratory chow and water in standard animal cages under a $12 \mathrm{~h}$ light/dark cycle.

The GluR $\delta 2^{\text {flox }}$ allele was identified by PCR using primers $5^{\prime}$ AGCAACCTACACTCCCAAAGAAG-3' (FD2P3) and 5'-ATTCAGTGCCAAGACAGACAACAA-3' (FD2P4) or by Southern blot hybridization analysis of NheI-digested genomic DNA with a $3^{\prime}$ probe. The
GluR $\delta 2^{\mathrm{CrePR}}$ allele was identified by PCR using $\mathrm{CreP} 1$ and $\mathrm{CreP} 2$ primers (Tsujita et al., 1999).

Induction of recombination. RU-486 (Sigma, St. Louis, MO) was suspended at a concentration of $50 \mathrm{mg} / \mathrm{ml}$ in water containing $0.25 \%(\mathrm{v} / \mathrm{v})$ carboxymethyl cellulose and $0.5 \%(\mathrm{v} / \mathrm{v})$ Tween 80 . We injected $1 \mathrm{mg} / \mathrm{g}$ body weight of RU-486 into the peritoneum of GluRS2 flox/flox and GluR $\delta 2^{\text {flox/CrePR }}$ mice at postnatal day 42 (P42)-P45 for 2 consecutive days. In situ hybridization analysis of $G l u R \delta 2$ mRNA was performed as described (Watanabe et al., 1993) using oligonucleotide probes 5'-ACCAAGCCCCCATCATCATTCGGGTTGCCAGAGTTGTGTATGGGA-3' and 5'-CTCTCAATGCGGGTGATAGTGAGGAAAGCGGCAAGGTTGGCTGTA-3' in mixture. Autoradiographic silver grains on PCs and the granular layer were counted to obtain the signal and noise levels, respectively. Quantitative immunoblotting analysis of GluR $\delta 2$ proteins in cerebellar homogenate was performed using rabbit anti-GluR $\delta 2$ antibody (Araki et al., 1993) and chemiluminescence (Amersham Biosciences, Piscataway, NJ). The images were acquired using a CCD camera (LAS-1000plus; Fuji Photo Film, Tokyo, Japan) and analyzed with Science Lab 98 Image Gauge (Fuji Photo Film). GluR $\delta 2$ signals were normalized with those of GluR $\epsilon 1$ (Watanabe et al., 1998) as an internal standard.

Histology and immunofluorescence. Under deep pentobarbital anesthesia (100 $\mu \mathrm{g} / \mathrm{g}$ of body weight, i.p.), mice were perfused transcardially with $4 \%$ paraformaldehyde in $0.1 \mathrm{M}$ sodium phosphate buffer, $\mathrm{pH} 7.4$, and processed for paraffin sections $(5 \mu \mathrm{m})$ with a sliding microtome (SM2000R; Leica Microsystems, Nussloch, Germany). Paraffin sections were stained with hematoxylin or immunostained with rabbit antiGluR $\delta 2$ antibody (Araki et al., 1993) and guinea pig anti-calbindin antibody (Nakagawa et al., 1998) followed by incubation with speciesspecific FITC- and Cy3-conjugated secondary antibodies (Jackson ImmunoResearch, West Grove, PA). Photographs were taken by a fluorescence microscope (AX-70; Olympus, Tokyo, Japan) or a confocal laser scanning microscope (Fluoview; Olympus).

Electron microscopy. For qualitative and quantitative analyses by conventional electron microscopy, ultrathin sections cut in the parasagittal plane were prepared from the straight portion of lobules $4 / 5$. Serial ultrathin sections were mounted on formvar-supported copper grids and stained with $2 \%$ uranyl acetate for 5 min and mixed lead solution for 2 $\mathrm{min}$. In each mouse, electron micrographs were taken randomly from the neuropil of the molecular layer. Electron micrographs were taken at an original magnification of $4000 \times$ or $10,000 \times$ using an $\mathrm{H}-7100$ electron microscope (Hitachi High-Technologies, Tokyo, Japan), and printed at a final magnification of $16,000 \times$ or $40,000 \times$. For measurement of active zone and postsynaptic density (PSD) lengths, electron micrographs were scanned and analyzed with MetaMorph software (Molecular Devices, Sunnyvale, CA). The two-dimensionally reconstructed images were drawn and processed for smoothing with Adobe Illustrator software (version 10; Adobe Systems, San Jose, CA). For phosphotungstic acid cytochemistry, microslicer sections (300 $\mu \mathrm{m}$ in thickness) were dehydrated in graded alcohols and incubated in $1 \%$ phosphotungstic acid in ethanol for $1 \mathrm{~h}$ and embedded in Epon812 resin.

Postembedding immunogold. For postembedding immunogold electron microscopy, microslicer sections ( $300 \mu \mathrm{m}$ in thickness) were cryoprotected with $30 \%$ glycerol in $0.1 \mathrm{~m}$ sodium phosphate buffer, $\mathrm{pH} 7.4$, and frozen rapidly in liquid propane in a cryofixation unit (CPC; Leica Microsystems). The specimens were transferred to $0.5 \%$ uranyl acetate in methanol in a cryosubstitution unit (AFS; Leica Microsystems) and embedded in Lowicryl HM20 resin (Electron Microscopy Sciences, Hatfield, PA). Serial ultrathin sections were mounted on Formvar-supported nickel grids for GluR $\delta 2$ labeling, whereas for PSD-93 and AMPA receptor labeling, single sections were mounted directly to nickel grids. For the single-section labeling, sections were etched with a saturated solution of $\mathrm{NaOH}$ in absolute ethanol for a few seconds. After blocking with $2 \%$ human serum albumin (Wako Pure Chemicals, Osaka, Japan) in $10 \mathrm{~mm}$ Tris-buffered saline, $\mathrm{pH}$ 7.6, grids were immunoreacted with rabbit antiGluR $\delta 2$ antibody $(20 \mu \mathrm{g} / \mathrm{ml})$ or rabbit anti-PSD-93 antibody $(20 \mu \mathrm{g} / \mathrm{ml})$ (Fukaya and Watanabe, 2000) or the mixture of rabbit anti-GluR1, -GluR2, and -GluR3 antibodies (20 $\mu \mathrm{g} / \mathrm{ml}$ each) (Shimuta et al., 2001) overnight and colloidal gold (10 nm)-conjugated anti-rabbit IgG (British Biocell International, Cardiff, UK) for 2 h. They were stained with $2 \%$ 


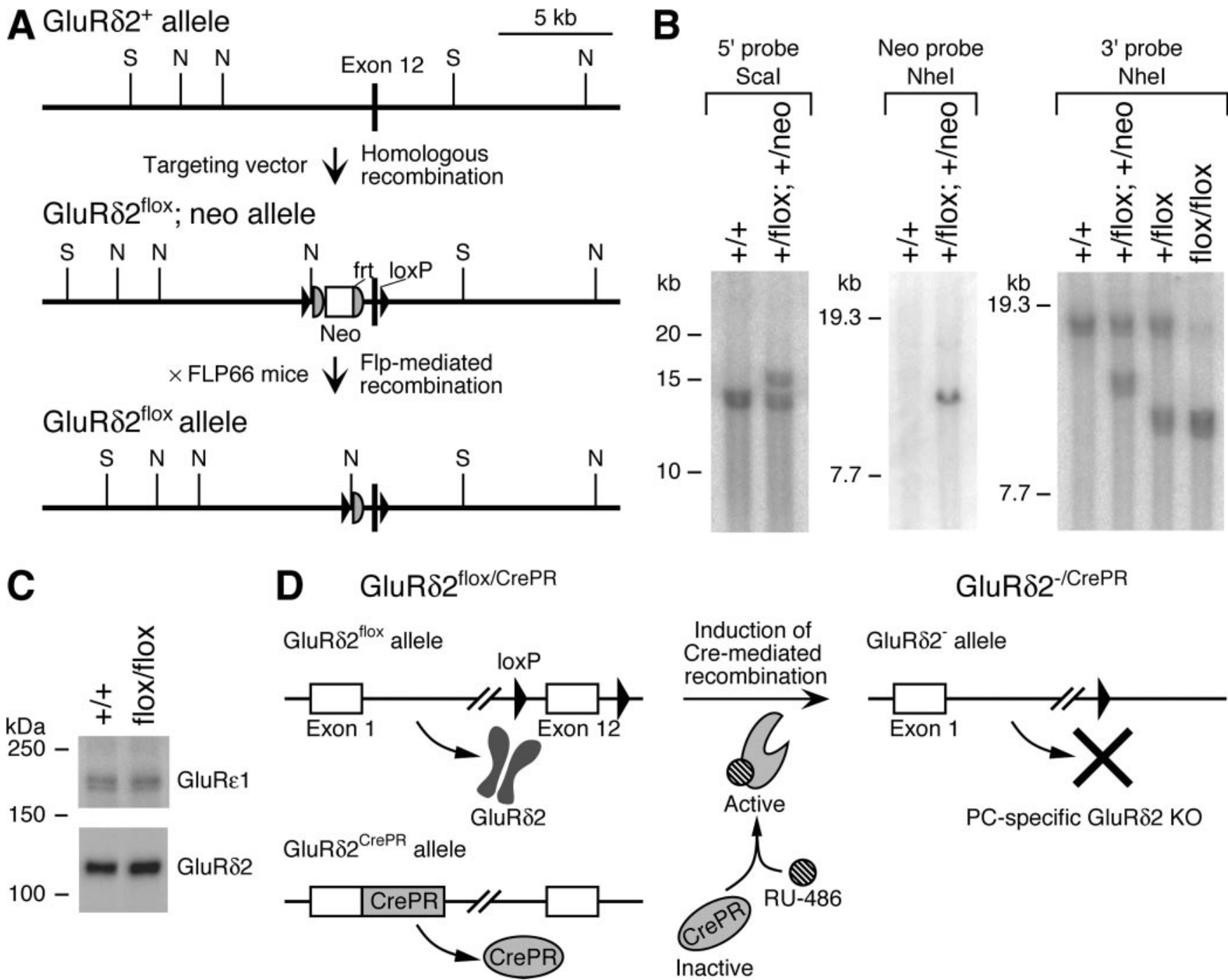

Figure 1. Inducible and PC-specific GluR $\delta 2$ gene ablation by CrePR-loxP recombination system. $A$, Schema of the exon 12 region of the GluR $\delta 2$ gene $\left(G l u R \delta 2^{+}\right)$, floxed and neo-inserted allele

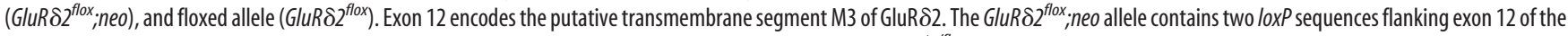
GluR $\delta 2$ gene and the neo gene flanked by two frt sequences. The neo gene was removed in vivo by crossing GluR $\delta 2^{+/ f l o x} ;+$ /neo mice with FLP 66 mice carrying the Flp recombinase gene under the

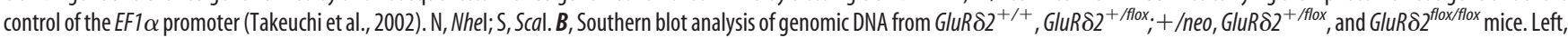
Scal-digested DNA hybridized with 5' probe; middle, Nhel-digested DNA hybridized with neo probe; right, Nhel-digested DNA hybridized with 3' probe. C, Western blot analysis of GluR $\delta 2$ and GluR $\epsilon 1$ proteins in cerebellar homogenates from GluR $\delta 2^{+/+}$and GluR $\delta 2^{f l o x}$ fllox mice. D, Schema for induction of cerebellar PC-specific GluR $\delta 2$ gene ablation in the adult brain. In GluR $\delta 2^{f l o x / \text { CrePR }}$ mice, one allele retains the intact GluR $\delta 2$ gene with loxP sequences, and the other is inactivated by insertion of the CrePR gene. RU-486 administration induces recombination by CrePR, leading to GluR $\delta 2$ gene knock-out in the adult brain in a cerebellar PC-specific manner.

uranyl acetate for $5 \mathrm{~min}$ and mixed lead solution for $30 \mathrm{~s}$. The background level was defined as the density of immunogold particles fell within $30 \mathrm{~nm}$ on both sides from the mitochondrial membrane (GluR $\delta 2$ and AMPA receptors) or presynaptic nonjunctional membrane (PSD-93).

Statistical analysis. Data were analyzed by Student's $t$ test or one-way ANOVA followed by Tukey-Kramer post hoc test.

\section{Results}

Inducible and cerebellar PC-specific GluR $\delta 2$ gene ablation To address the functional roles of cerebellar PC-specific GluR $\delta 2$ in the adult brain by inducible Cre-mediated recombination, we constructed a targeting vector in which two loxP sequences were

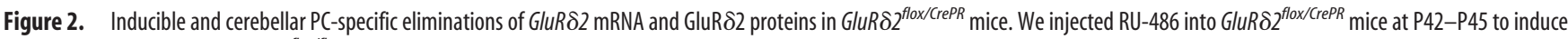
CrePR recombinase activity. GluR $\delta 2^{f l o x}$ fflox mice injected with the antiprogestin served as controls. Temporal patterns of cerebellar PC-specific elimination of the GluR $\delta 2 \mathrm{mRNA}$ and GluR $\delta 2$ proteins

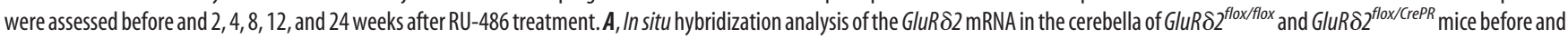
2,4 , and 8 weeks after drug treatment. Parasagittal sections were hybridized with ${ }^{33} \mathrm{P}$-labeled oligonucleotide probes and counterstained with methyl green-pyronine. Arrowheads indicate strongly

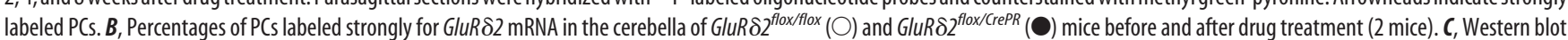

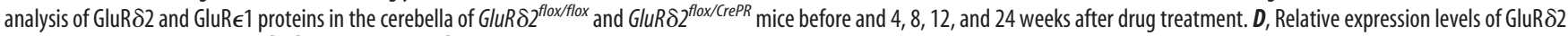

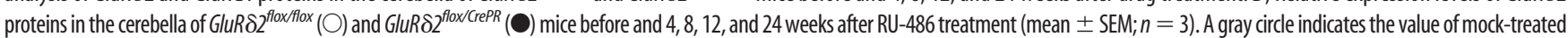
GluR $\delta 2^{f f o x / C r e P R}$ mice $(n=3)$. The amounts of GluR $\delta 2$ proteins in GluR $\delta 2^{f l o x / C r e P R}$ mice before drug treatment were taken as $100 \%$. E, Immunohistochemical analysis of GluR $\delta 2$ proteins in the cerebella of

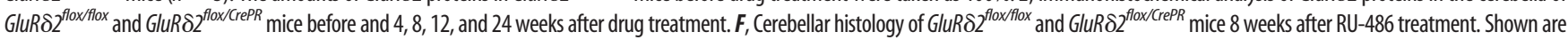
hematoxylin staining and immunofluorescence for calbindin (green) and GluR $\delta 2$ (red) in the molecular layer of the cerebellum. Scale bars: $A, 20 \mu \mathrm{m} ; \boldsymbol{E}, 1 \mathrm{~mm} ; \boldsymbol{F}, 50 \mu \mathrm{m}$. 


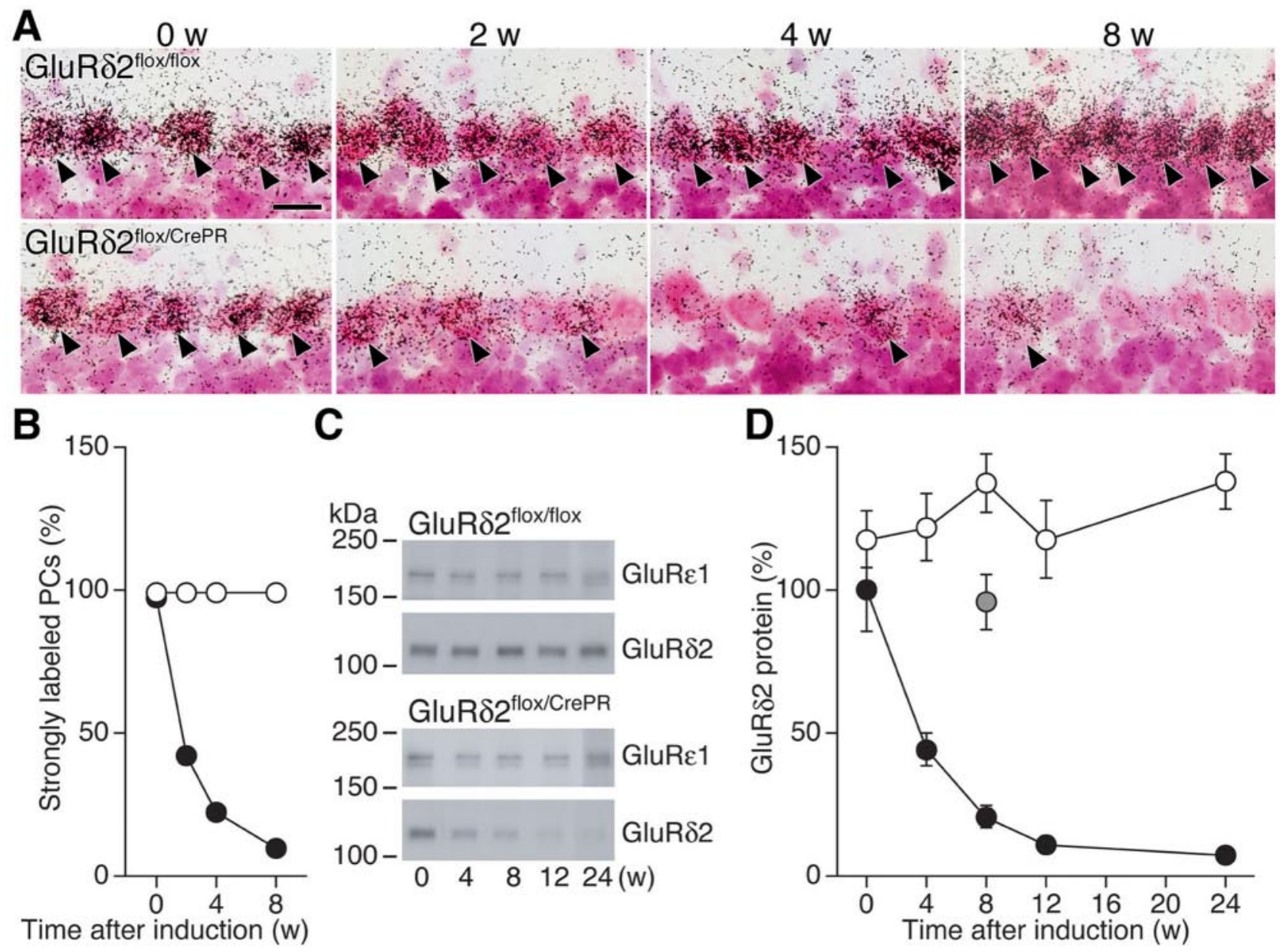

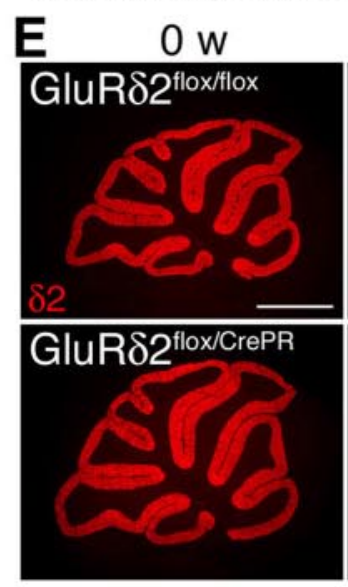

F

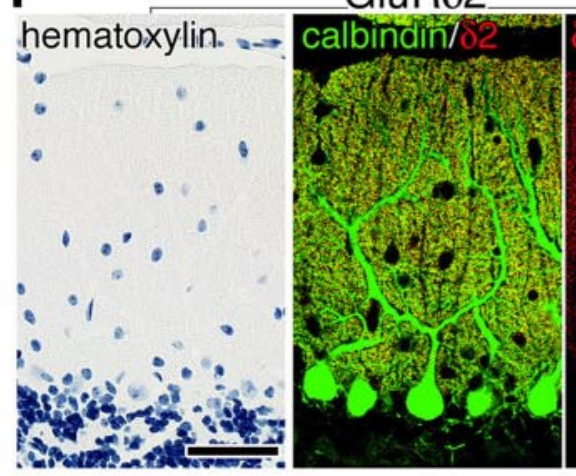

$4 w$
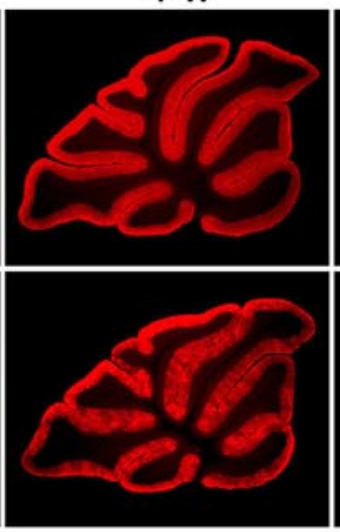

GluR $\delta 2^{\text {flox/flox }}$

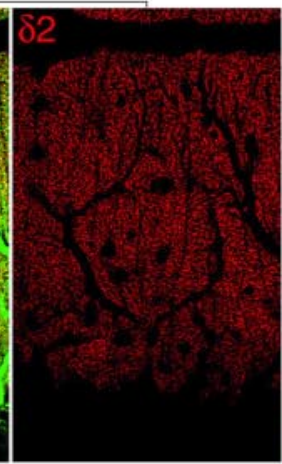

$8 w$
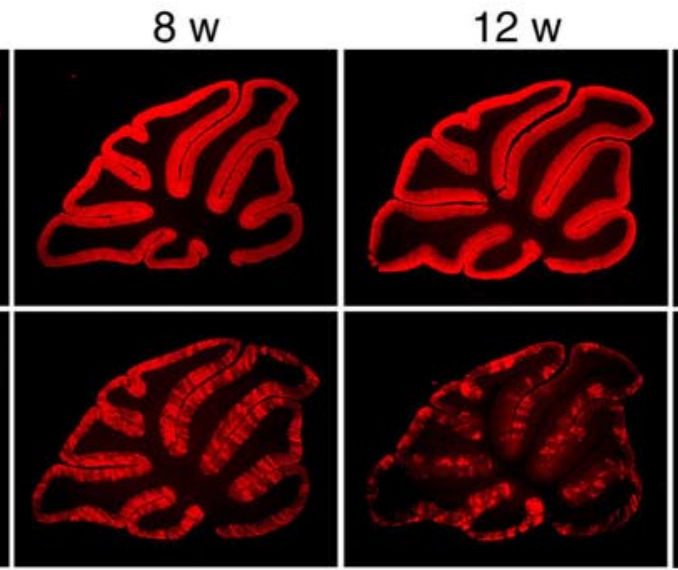

GluR $\delta 2^{\text {flox/CrePR }}$

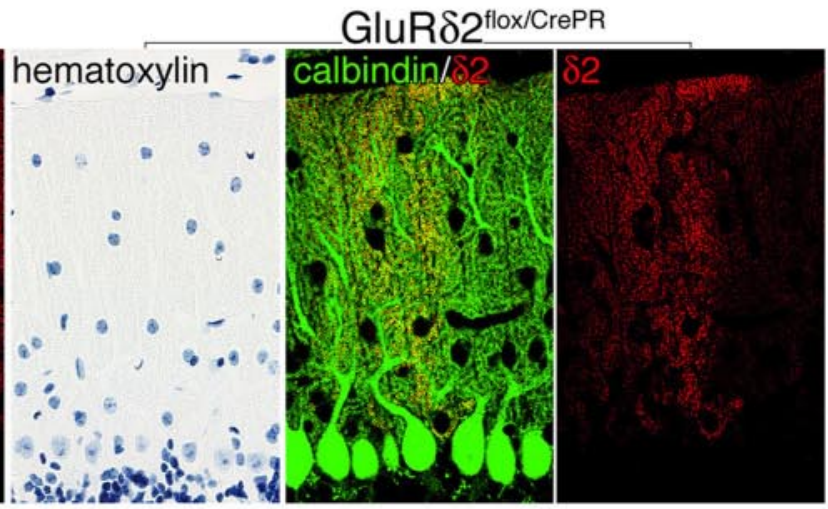


inserted into the mouse GluR $\delta 2$ gene isolated from the C57BL/6 strain. The first loxP sequence linked to the neo gene flanked by two frt sites was in the intron upstream of exon 12 encoding putative transmembrane segment M3, and the second one was in the intron downstream of exon 12. Using a subline of ES cells derived from the C57BL/6 strain (Köntgen et al., 1993), we obtained recombinant GluR $\delta 2^{+/ \text {flox }}$; / neo mice (Fig. 1 A). By crossing to FLP66 transgenic mice of the C57BL/6 strain carrying an Flp recombinase expression vector under the control of the $E F 1 \alpha$ promoter (Takeuchi et al., 2002), we successfully eliminated the neo gene to yield GluR $\delta 2^{+/ f l o x}$ mice with the GluR $\delta 2$ gene flanked by two loxP sequences (Fig. $1 B$ ). The expression of GluR $\delta 2$ proteins was comparable between $G l u R \delta 2^{+/+}$and $G l u R \delta 2^{\text {flox/flox }}$ mice (Fig. 1C).

We crossed GluR $\delta 2^{\text {flox/flox }}$ target mice with $G l u R \delta 2^{+/ C r e P R}$ mice carrying the $C r e P R$ gene inserted into the $G l u R \delta 2$ gene and thus were capable of mediating Cre-loxP recombination selectively in cerebellar PCs after induction (Kitayama et al., 2001). The resulting GluR $\delta 2^{\text {flox/CrePR }}$ mice carrying the floxed GluR $\delta 2$ gene on one allele and the CrePR gene on the other grew and mated normally. To examine the functional roles of GluR $\delta 2$ in the adult cerebellum, we induced the recombinase activity of CrePR by intraperitoneal injection of antiprogestin RU-486 into $G l u R \delta 2^{\text {flox/CrePR }}$ mice at P42-P45 for 2 consecutive days when cerebellar wiring was well completed and fully established PF-PC synapses were functional (Fig. $1 D$ ). GluR $\delta 2^{\text {flox/flox }}$ mice treated with RU-486 served as controls. We first examined the expression of the GluR $\delta 2$ mRNA in cerebellar PCs by in situ hybridization before and at 2, 4, and 8 weeks after RU-486 injection (Fig. 2A). Before antiprogestin administration, strong hybridization signals, defined as those with the signal-to-noise ratio $>4.0$, were found in almost all PCs of both GluR $\delta 2^{\text {flox/CrePR }}(98 \% ; n=2)$ and GluR $\delta 2^{\text {flox/flox }}(100 \% ; n=2)$ mice. RU-486 exerted little effect on the percentage of hybridization-positive PCs in GluR $\delta 2^{\text {flox/flox }}$ mice ( $100 \%$ at 8 weeks after injection). In GluR $\delta 2^{\text {flox } / C r e P R}$ mice, however, the percentage of hybridization-positive PCs decreased to $23 \%$ at 4 weeks after RU-486 injection and gradually decreased thereafter with a reciprocal increase of PCs with low or no hybridization signals for the GluR $\delta 2$ mRNA (Fig. $2 B$ ).

We then estimated the amounts of GluR $\delta 2$ proteins by immunoblot analysis, comparing those of NMDA receptor GluR $\epsilon 1$ proteins that are expressed in cerebellar granule cells but not in PCs (Yamada et al., 2001) as internal standards (Fig. 2C,D). The amounts of GluR $\delta 2$ proteins in GluR $\delta 2^{\text {flox/flox }}$ mice were essentially unaffected by RU- 486 treatment. In contrast, GluR $\delta 2$ proteins gradually decreased to $21 \%$ at 8 weeks after RU-486 injection, indicating successful GluR $\delta 2$ gene knock-out in mature PCs by the CrePR-antiprogestin induction system. GluR $\delta 2^{\text {flox/CrePR }}$ mice at 8 weeks after mock treatment showed no decrease in the amount of GluR $\delta 2$ proteins (Fig. 2D). We further stained parasagittal cerebellar sections with anti-GluR $\delta 2$ antibody (Fig. $2 E$ ). Before induction, intense GluR $\delta 2$ immunoreactivity was present in the molecular layer of both GluR $\delta 2^{\text {flox } / C r e P R}$ and $G l u R \delta 2^{\text {flox/flox }}$ mice. RU-486 treatment of GluR $\delta 2^{\text {flox/flox }}$ mice exerted little effect on GluR $\delta 2$ signals. In GluR $\delta 2^{\text {flox/CrePR }}$ mice, however, A heterogeneous decrease of GluR $\delta 2$ immunoreactivity was discernable at 4 weeks after RU-486 injection. At 8 weeks, chimeric patterns of GluR $\delta 2$ signals became apparent with alternating strong and pale immunofluorescent bands in the molecular layer. At 12 weeks, pale or blank bands expanded in the molecular layer, being separated by thin bands with strong GluR $\delta 2$ immunoreactivity. The conditional ablation of GluR $\delta 2$ induced by RU-486 injection was not preferential in particular lobules or regions and occurred rather evenly in the anteroposterior and mediolateral axes of the cerebellum. Multiple factors may account for the relatively slow time course of GluR $\delta 2$ ablation. Knock-down of GluR $\delta 2$ mRNA below the detection level in $80 \%$ of PCs took 4 weeks after administration of RU-486, suggesting a time lag between druginduced activation of CrePR and mRNA degradation. Loss of $80 \%$ of GluR $\delta 2$ proteins took an additional 4 weeks, suggesting a slow turnover rate of GluR $\delta 2$ proteins.

The cerebellum of the RU-486-treated GluR $\delta 2^{\text {flox/CrePR }}$ mice exhibited normal foliation and laminated cortical structures (Fig. $2 E)$. No apparent differences were detectable in the thickness of the molecular and granular layers between $G l u R \delta 2^{\text {flox/CrePR }}$ and GluR $\delta 2^{\text {flox/flox }}$ mice until 12 weeks after RU-486 treatment. Double immunostaining for GluR $\delta 2$ and calbindin revealed that PCs extended well arborized dendrites studded with numerous spines in GluR $\delta 2^{\text {flox } / C r e P R}$ and GluR $\delta 2^{\text {flox/flox }}$ mice at 8 weeks after RU486 treatment (Fig. $2 F$ ), indicating that the chimeric patterns of GluR $\delta 2$ immunoreactivity were not caused by the loss of PCs or distorted arborization of dendrites.

\section{Appearance of synaptic mismatching and free spines}

By electron microscopy, we inspected structures of PF-PC synapses in GluR $\delta 2^{\text {flox/CrePR }}$ and GluR $\delta 2^{\text {flox/flox }}$ mice at 8 weeks after RU-486 treatment; treated GluR $\delta 2^{\text {flox/CrePR }}$ and GluR $\delta 2^{\text {flox/flox }}$ mice were hereafter called mutant and control mice, respectively. Asymmetrical synapses were the most frequent type of synapses in the molecular layer of the cerebellum, and most of them were identified as PF-PC synapses on the basis of their characteristic morphology (Miyazaki et al., 2004). On single electron micrographs, all PC spines having PSD formed synaptic contacts with PFs in control mice (Fig. 3A). In mutant mice, however, some PC spines possessing PSD lacked presynaptic counterparts, suggesting the emergence of free spines (Fig. 3B, f). Furthermore, we noted that PSD in some contacted spines extended over the apposed active zone (Fig. $3 B$, arrows). In contrast, active zone and PSD were well matched in control mice (Fig. $3 A$ ).

We then examined randomly sampled PC spines by serial electron microscopy. In control mice, all PC spines had synaptic contacts with PF terminals (Fig. 3C). The analysis convincingly demonstrated the emergence of PC spines free from synaptic contacts in mutant mice, and they were thoroughly surrounded by cytoplasmic sheets of Bergmann glia (Fig. 3D). In such free spines, PSD-like condensation was present but was apparently smaller in size. These free spines were reminiscent of those found in GluR $\delta 2$ null mutant mice (Kashiwabuchi et al., 1995; Kurihara et al., 1997).

Serial electron microscopy further enabled us to precisely classify PC spines of mutant mice as those forming matched contact, those forming mismatched contact, and free spines. For quantitative comparison, we defined a synapse as mismatched when the edges of the active zone and PSD were $>100 \mathrm{~nm}$ apart in any of its serial sections. Under this criterion, almost all PC spines in control mice were classified as normal matched synapses [99.2 \pm $0.6 \%$ (mean $\pm \mathrm{SEM}$ ); $n=359$; three mice] (Fig. $3 E$ ). In contrast, $17.1 \pm 3.3 \%$ of PC spines in mutant mice $(n=358$; three mice $)$ were free from synaptic contacts and $13.1 \pm 2.7 \%$ had mismatched contacts with PF terminals (Fig. $3 G, H$ ). Such mismatching between the active zone and PSD was further confirmed by phosphotungstic acid cytochemistry that selectively visualizes electron-opaque materials in the active zone, synaptic cleft, and PSD (Bloom and Aghajanian, 1966) (Fig. 3I-L). Twodimensional extents of the active zone and PSD were reconstructed from serial sections (Fig. $3 M-P$ ); when superimposed, 
GluR $\delta 2^{\text {flox/flox }}$
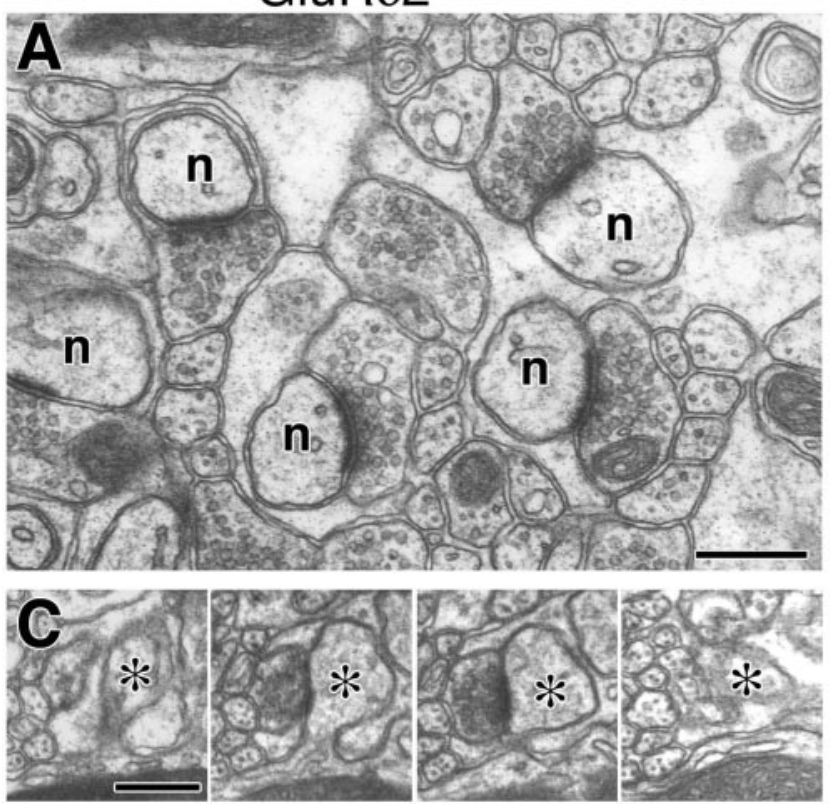

\section{GluR $\delta 2^{\text {flox/flox }}$}
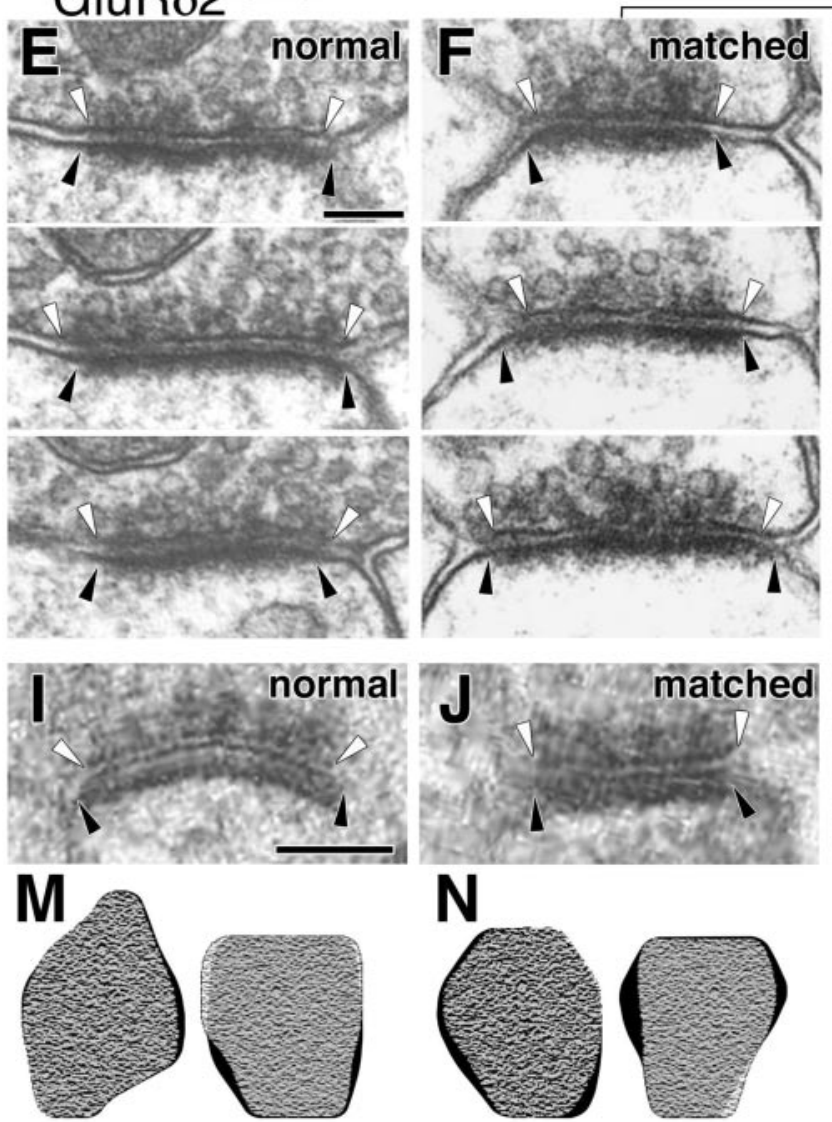
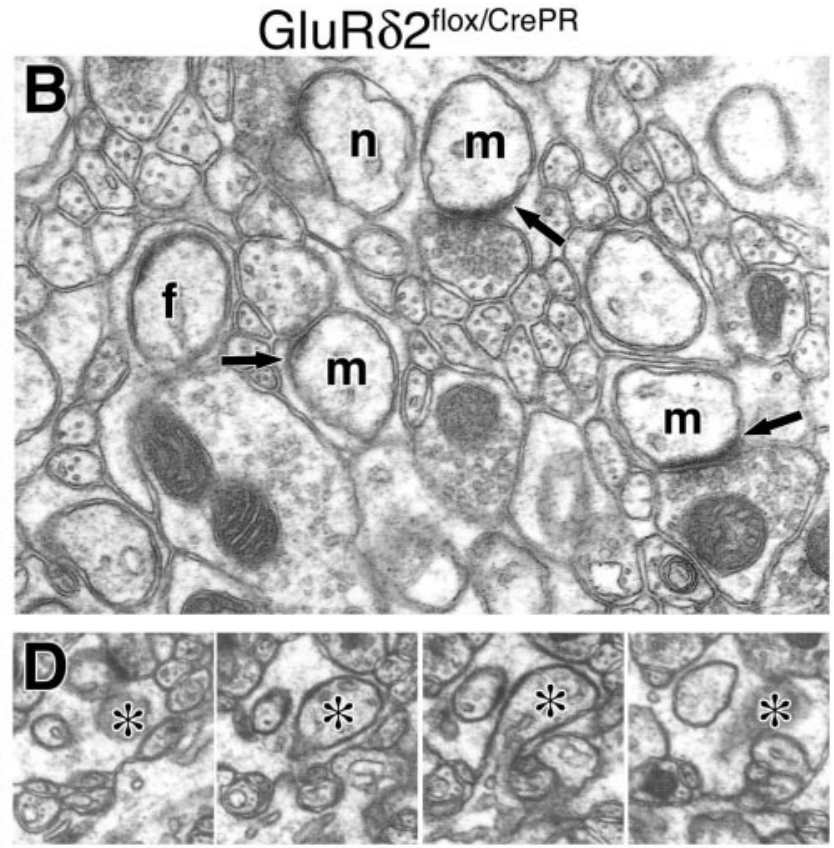

GluR $\delta 2^{f l o x / C r e P R}$
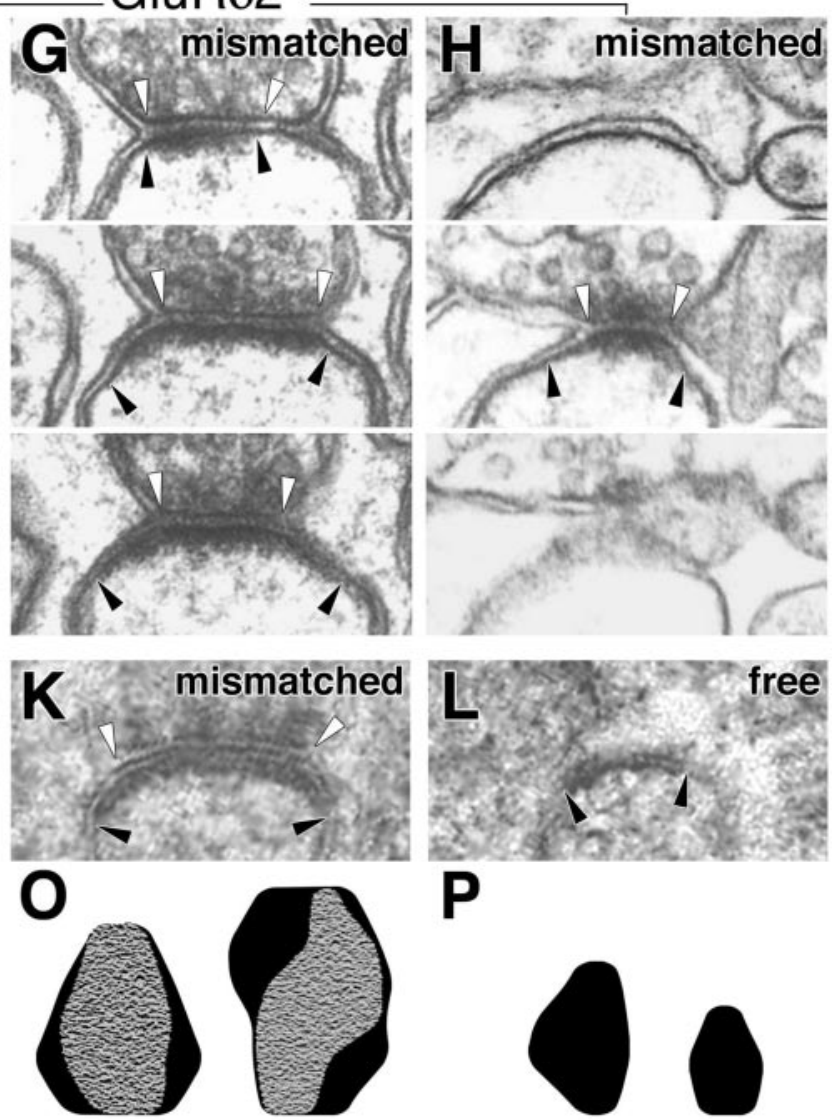

$\mathbf{P}$

Figure 3. Emergence of mismatched PF-PC synapses and free PC spines. RU-486-treated GluR $\delta 2^{\text {floxfflox }}$ mice served as controls. $A$, Normal synapses $(\mathrm{n})$ in the cerebellum of a control mouse (RU-486-treated GluR $\delta 2^{f l o x}$ /flox mouse). Active zone and PSD are matched at all PF-PC synapses. B, Mismatched synapses $(\mathrm{m})$ and free spines (f) in the cerebellum of a mutant mouse (RU-486treated GluR $\delta 2^{\text {flox/(rePR }}$ mouse). Arrows indicate the mismatch between active zone and PSD at PF-PC synapses. $\boldsymbol{C}, \boldsymbol{D}$, Serial images of a normal synapse in the control cerebellum $(\boldsymbol{C})$ and of a free spine in the mutant cerebellum $(\boldsymbol{D})$. Asterisks indicate dendritic spines of PCS. $\boldsymbol{E}-\boldsymbol{H}$, Serial images through normal $(\boldsymbol{E})$, matched $(\boldsymbol{F})$, and mismatched $(\boldsymbol{G}, \boldsymbol{H})$ synapses. White and black arrowheads indicate the edges of active zone and PSD, respectively. $\boldsymbol{I}-\boldsymbol{L}$, Phosphotungstic acid cytochemistry of a normal synapse in the control cerebellum $(\boldsymbol{I})$ and matched $(\boldsymbol{J})$ and mismatched $(\boldsymbol{K})$ synapses and a free spine $(\boldsymbol{L})$ in the mutant cerebellum. White and black arrowheads indicate the edges of active zone and PSD, respectively. $\boldsymbol{M}-\boldsymbol{P}$, Two-dimensionally reconstructed images of active zone (gray) and PSD (black) at normal $(\boldsymbol{M})$, matched $(\boldsymbol{N})$, and mismatched synapses $(\boldsymbol{O})$, and free spines $(\boldsymbol{P})$. Reconstruction was accomplished by stacking and smoothing images of three to six serial sections in the vertical axis. Linear outlines in the top and bottom sides are caused by the omission of sections through the margin of synapses, which were inappropriate for structural identification and reconstruction. Scale bars: $A, C, 500 \mathrm{~nm} ; \boldsymbol{E}, I, \boldsymbol{M}, 200 \mathrm{~nm}$. 
these extents of the active zone and PSD overlapped at all synapses in control mice, thus being normal synapses (Fig. 3M). At mismatched synapses in mutant mice, PSD was irregularly expanded over the apposed active zone (Fig. 3O). Interestingly, some synapses classified as matched in mutant mice showed a dissociating tendency between active zone and PSD (Fig. $3 F, N$ ). Free spines had PSD, but the areas were smaller than those at normal, matched, and mismatched synapses (Fig. 3P). Free spines and mismatched synapses were hardly detectable in GluR $\delta 2^{\text {flox/CrePR }}$ mice at 8 weeks after mock treatment $(n=300$; three mice).

\section{Ablation of GluR $\delta 2$ proteins and structural alterations at PF-PC synapses}

We applied postembedding immunogold to examine whether these structural alterations at PC synapses correlate with GluR $\delta 2$ protein levels at individual synapses. The labeling density per 1 $\mu \mathrm{m}$ of PSD length was determined by measuring the total number of gold particles and the total length of PSD appearing on serial sections through a given synapse (Fig. 4). The mean labeling density at normal synapses in control mice was $14.8 \pm 0.9(n=$ 46; three mice) (Fig. $4 A, E$ ). In mutant mice, the mean GluR $\delta 2$ labeling density decreased in the order of matched synapses (9.2 $\pm 0.7 ; n=65$; three mice) (Fig. $4 B, F)>$ mismatched synapses $(5.4 \pm 0.6 ; n=44)$ (Fig. $4 C, G)>$ free spines $(0.2 \pm 0.2 ; n=$ 18) (Fig. $4 D, H)$; the background density was $0.2 \pm 0.1(n=56$; total measured length, $116.4 \mu \mathrm{m})$. There were significant differences in the GluR $\delta 2$ labeling among matched synapses, mismatched synapses, and free spines in mutant mice (ANOVA, $F_{(2,124)}=26.9, p<0.0001$; post hoc test, $\left.p<0.01\right)$. Furthermore, the GluR $\delta 2$-labeling density in the dissociated portion of PSD at mismatched synapses ( $1.2 \pm 0.7 ; n=44$; three mice $)$ was very low and close to that of free spines, whereas the density in the contacted portion at mismatched synapses $(6.8 \pm 0.7)$ was close to that of matched synapses. Thus, the density in the dissociated portion was much smaller than that in the contacted portion $(t$ test; $p<0.0001)$.

\section{Changes in sizes of the active zone and PSD}

From serial profiles of a given classified synapse, we chose a single profile having the largest PSD to compare the length of active zone and PSD ( 45 synapses from three control mice; 43 matched and 39 mismatched synapses and 28 free spines from three mutant mice). As shown in Figure $5 A$ by cumulative frequency plots, the length of active zone decreased significantly in the order of normal synapses in control mice $(348 \pm 12 \mathrm{~nm})>$ matched synapses in mutant mice $(296 \pm 10 \mathrm{~nm})>$ mismatched synapses in mutant mice $(252 \pm 10 \mathrm{~nm})$ (ANOVA, $F_{(2,124)}=19.1, p<$ 0.0001 ; post hoc test, $p<0.01$ for normal vs matched or mismatched; $p<0.05$ for matched vs mismatched). Thus, the sizes of active zone corresponded well with the densities of GluR $\delta 2$ immunogold particles. The length of PSD decreased significantly in the order of normal synapses in control mice $(379 \pm 13 \mathrm{~nm})>$ matched synapses in mutant mice $(332 \pm 10 \mathrm{~nm})>$ free spines in mutant mice $(226 \pm 11 \mathrm{~nm})$, but increased at mismatched synapses in mutant mice $(424 \pm 12 \mathrm{~nm})\left(\right.$ ANOVA, $F_{(3,151)}=43.1$, $p<0.0001$; post hoc test, $p<0.01$ for normal vs free, matched vs mismatched or free, and mismatched vs free; $p<0.05$ for normal vs matched or mismatched) (Fig. $5 B$ ). Consequently, the ratio of active zone to PSD lengths at mismatched synapses $(0.59 \pm 0.01)$ was significantly smaller than that at normal $(0.92 \pm 0.01)$ and matched synapses $(0.89 \pm 0.01)\left(\right.$ ANOVA, $F_{(2,124)}=167, p<$ 0.0001 ; post hoc test, $p<0.01$ ) (Fig. 5C).

\section{GluR $\delta 2^{\text {flox/flox }}$}
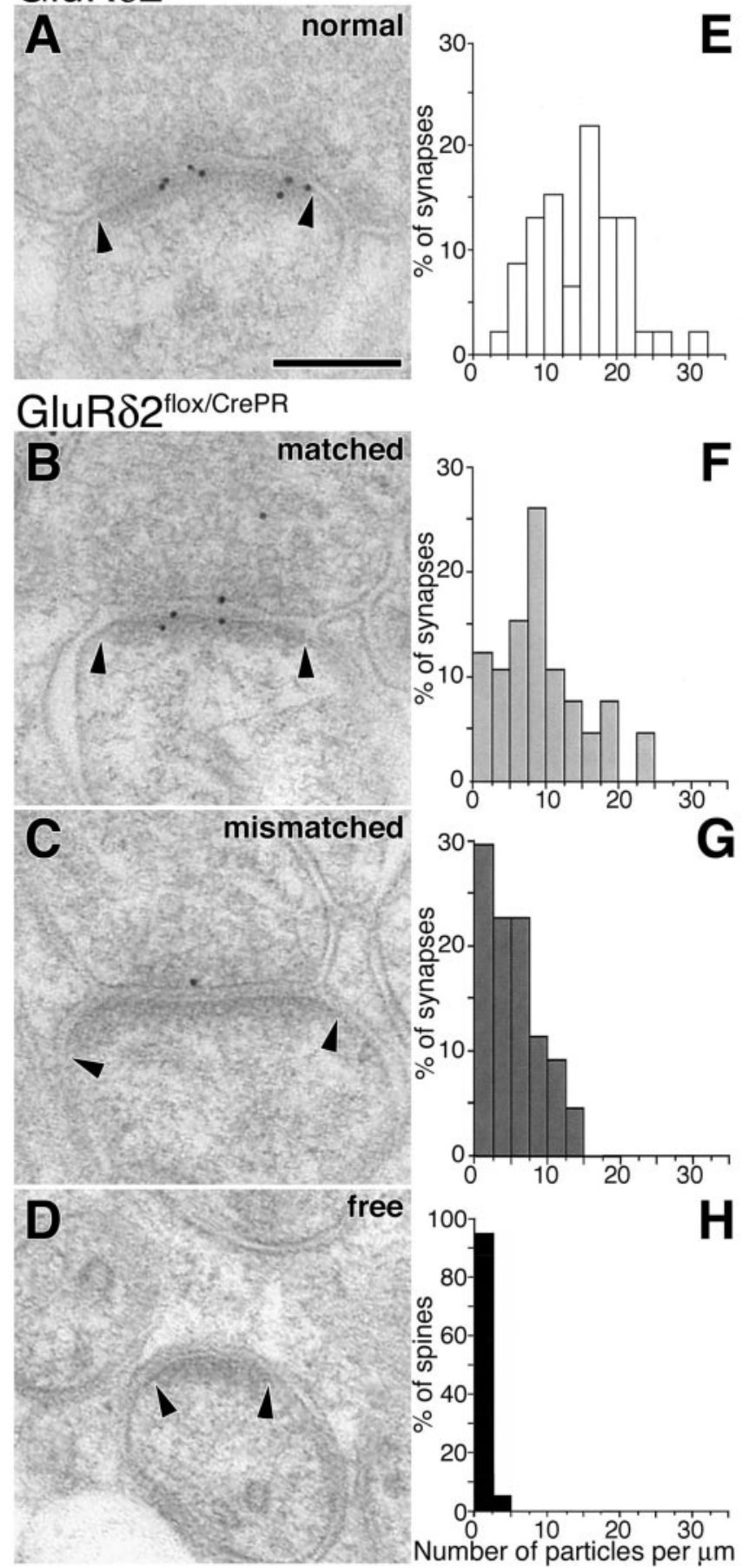

Figure 4. Immunogold electron microscopic analysis of GluR $\delta 2$ proteins. $A-D$, Immunogold labeling for GluR $\delta 2$ proteins at a normal synapse in a control mouse $(\boldsymbol{A})$ and at a matched synapse $(\boldsymbol{B})$, a mismatched synapse $(\boldsymbol{C})$ and a free spine $(\boldsymbol{D})$ in a mutant mouse. Arrowheads indicate the edge of PSD. Scale bar, $200 \mathrm{~nm}$. $\boldsymbol{E}-\boldsymbol{H}$, Histograms for GluR $\delta 2$-labeling densities per $1 \mu \mathrm{m}$ of PSD length at normal $(\boldsymbol{E})$, matched synapses $(\boldsymbol{F})$, mismatched synapses $(\boldsymbol{G})$, and free spines $(\boldsymbol{H})$. The number of labeled synapses was 46 of 46 for normal synapses, 60 of 65 for matched synapses, 41 of 44 for mismatched synapses, and 1 of 18 for free spines. Of the 41 labeled mismatched synapses, immunogold labeling at the contacted and dissociated portions was detected at 41 or 4 synapses, respectively.

\section{Effect of GluR $\delta 2$ ablation on postsynaptic distributions of} PSD-93 and AMPA receptor proteins

We further examined the effect of GluR $\delta 2$ ablation after the distribution of PSD-93 and AMPA receptors at PF-PC synapses 

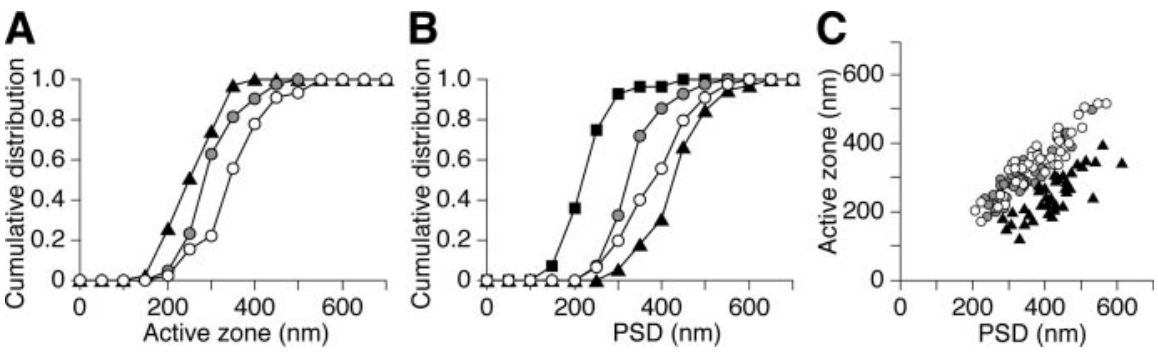

Figure 5. Lengths of the active zone and PSD. $A, B$, Cumulative frequency plots of active zone length $(\boldsymbol{A})$ and PSD length $(\boldsymbol{B})$ at normal synapses in control mice (open circles) and at matched synapses (filled circles), mismatched synapses (triangles), and free spines (squares) in mutant mice. C, Scattergram plot between active zone and PSD lengths at normal (open circles), matched (filled circles), and mismatched synapses (triangles).

(Zhao et al., 1998; Roche et al., 1999; Fukaya and Watanabe, 2000) by postembedding immunogold. Because the labeling density for PSD-93 and AMPA receptors was much lower than that for GluR $\delta 2$, immunogold was applied to single sections, in which both sides of the sections are immunoreacted, thus leading to an increase in the sensitivity and accuracy of detection.

In mutant mice, the mean PSD-93-labeling density decreased in the order of matched synapses $>$ mismatched synapses $>$ free spines (Fig. 6A). There were significant differences in the PSD-93 labeling among matched synapses, mismatched synapses, and free spines in mutant mice (ANOVA, $F_{(2,429)}=9.1, p=0.0001$; post hoc test, $p<0.05$ for matched vs mismatched; $p<0.01$ for matched vs free). Furthermore, at mismatched synapses, the PSD-93-labeling density was higher in the contacted portion of PSD than in the dissociated portion (Fig. 6B), showing a significant difference ( $t$ test; $p=0.03$ ).

PCs express high levels of AMPA receptor subunits, GluR1, GluR2, and GluR3 (Keinänen et al., 1990), and all of them are localized at PF synapses (Zhao et al., 1998). To further increase the labeling density of AMPA receptors, we used a mixture of antibodies against the GluR1, GluR2, and GluR3 subunits. In mutant mice, the mean AMPA receptor-labeling density decreased in the order of matched synapses $>$ mismatched synapses $>$ free spines (Fig. 6C). There were significant differences in the AMPA receptor labeling among matched synapses, mismatched synapses, and free spines in mutant mice (ANOVA, $F_{(2,407)}=9.6, p<0.0001$; post hoc test, $p<0.01$ for matched vs mismatched or free). There were no significant differences in the AMPA receptor-labeling density between the contacted and dissociated portions of PSD at mismatched synapses $(t$ test; $p=$ 0.10) (Fig. 6D).

\section{Temporal patterns of structural alterations at PF-PC synapses}

We then examined the appearance of mismatched synapses and free spines in GluR $\delta 2^{\text {flox/flox }}$ and GluR $\delta 2^{\text {flox/CrePR }}$ mice before and at $4,8,12$, and 24 weeks after RU-486 administration. Before antiprogestin treatment, there were very few, if any, free spines and mismatched synapses with PF terminals in both types of mice (Fig. $7 A, B$ ). After RU-486 administration, a significant number of mismatched synapses and free spines appeared at 4 weeks in $G l u R \delta 2^{\text {flox/CrePR }}$ mice, and their fractions increased progressively toward 24 weeks (Fig. 7E). At 24 weeks, $42.0 \pm 2.7 \%$ of PC spines ( $n=300$; three mice) were free from synaptic contacts with PFs and $28.3 \pm 3.4 \%$ of spines had mismatched synapses, whereas matched synapses occupied only $29.7 \pm 5.9 \%$ (Fig. 7D). On the other hand, free spines and mismatched synapses were very rare in antiprogestin-treated $G l u R \delta 2^{\text {flox/flox }}$ mice even at 24 weeks after treatment (Fig. 7C).

\section{Discussion}

Neurobiological and behavioral traits are fairly complex and are most probably influenced by a large number of genes as well as environmental factors. There is ample evidence for large genetic differences between inbred mouse strains at the neurobiological and behavioral levels (Plomin, 1990; Wolfer et al., 1997). The inducible and neuron-specific gene targeting system developed in this study will be useful for dissecting the molecular basis of the structure and function of the adult brain under the pure C57BL/6 genetic background. Here we show that inducible ablation of GluR $\delta 2$ in the adult cerebellum resulted in mismatching between the active zone and PSD at PF-PC synapses. Furthermore, a significant number of PC spines became free from PF terminals. We thus identified GluR $\delta 2$ as a key molecule that regulates presynaptic and postsynaptic matching and synaptic connection in the adult brain. These results provide evidence for the notion that there is a common molecular mechanism underlying synaptic plasticity and synapse formation in the cerebellum (Kashiwabuchi et al., 1995). A number of molecules, including GluRs, receptor tyrosine kinases, and cell adhesion molecules, have been implicated in synapse formation and morphological maturation of dendritic spines during development (Hering and Sheng, 2001; Goda and Davis, 2003; Scheiffele, 2003), but the molecular basis of synaptic connection and its modulation in the adult brain are poorly understood. There is ample evidence for the involvement of NMDA receptors in synapse refinement in vivo during development and in structural modification of dendritic spines in cultured neurons (Goodman and Shatz, 1993; Engert and Bonhoeffer, 1999; Maletic-Savatic et al., 1999); however, no structural alterations were found at synapses by conditional ablation of NMDA receptors in the adult brain (Tsien et al., 1996; Rampon et al., 2000). In cultured hippocampal neurons, the AMPA receptor GluR2 subunit was important for morphogenesis of dendritic spines (Passafaro et al., 2003). On the other hand, no abnormalities in synaptic structures were detectable in mutant mice lacking the AMPA receptor GluR2 subunit (Sans et al., 2003; Petralia et al., 2004). Additional studies will be required to examine whether molecular determinants of synaptic structures during development are also important for modifications of synaptic structures in the adult brain. The present investigation provides direct evidence that GluR $\delta 2$ does regulate presynaptic and postsynaptic matching and synaptic connections in the adult cerebellum.

Immunogold labeling of GluR $\delta 2$ proteins under electron microscopy revealed that in mutant mice, the density of gold particles was reduced more at mismatched synapses than at matched synapses. Furthermore, the density of GluR $\delta 2$-labeling particles at mismatched synapses in mutant mice was much lower than that at normal synapses of control mice. Thus, certain amounts of GluR $\delta 2$ proteins in PSD are critical for proper matching of presynaptic and postsynaptic specializations. Consistently, GluR $\delta 2-$ labeling particles were scarcely detectable in free PC spines of mutant mice. In addition, the fractions of mismatched synapses and free spines in total PC spines progressively increased concomitantly with the gradual decrease of GluR $\delta 2$ proteins after 

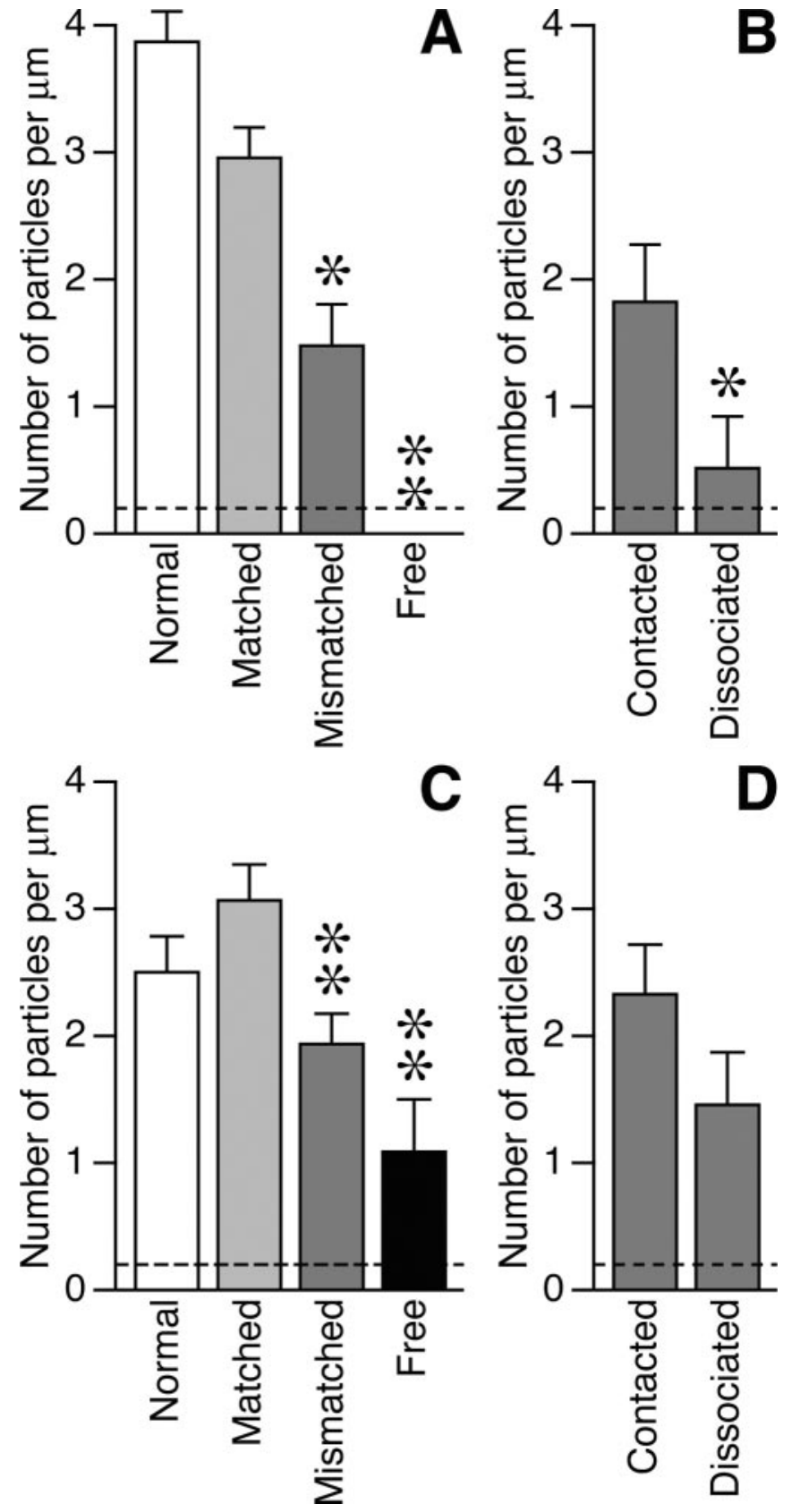

Figure 6. Immunogold electron microscopic analysis of PSD-93 and AMPA receptor proteins. $A$, PSD-93-labeling densities per $1 \mu \mathrm{m}$ of PSD length at normal synapses in three control mice and at matched synapses, mismatched synapses, and free spines in three mutant mice. The number of labeled synapses was 208 of 320 for normal synapses, 173 of 357 for matched synapses, 18 of 53 for mismatched synapses, and 0 of 22 for free spines. The background density was $0.2 \pm 0.1(n=53$; total measured length, $58.7 \mu \mathrm{m}) . \boldsymbol{B}$, PSD-93-labeling densities in the contacted and dissociated portions of PSD at mismatched synapses in three mutant mice. Of the 18 labeled mismatched synapses, immunogold labeling at the contacted and dissociated portions was detected at 16 or 2 synapses, respectively. C, AMPA receptor-labeling densities per 1 $\mu \mathrm{m}$ of PSD length at normal synapses in three control mice and at matched synapses, mismatched synapses, and free spines in three mutant mice. The number of labeled synapses was 98 of 225 for normal synapses, 121 of 231 for matched synapses, 64 of 123 for mismatched synapses, and 9 of 56 for free spines. The background density was $0.2 \pm 0.1$ ( $n=37$; total measured length, $36.8 \mu \mathrm{m}$ ). D, AMPA receptor-labeling densities in the contacted and dissociated portions of PSD at mismatched synapses in three mutant mice. Of the 64 labeled mismatched synapses, immunogold labeling at the contacted and dissociated portions was detected at 53 or 15 synapses, respectively. Error bars represent SEM. Dotted lines indicate background densities. ${ }^{*} p<0.05 ;{ }^{* *} p<0.01$. antiprogestin induction of CrePR-mediated GluR $\delta 2$ gene knockout in GluR $\delta 2^{f l o x / C r e P R}$ mice. Thus, structural changes at PF-PC synapses appear to proceed from normal contacts via mismatched contacts to free spines according to the reduction of synaptic contents of GluR $\delta 2$ protein. As the density of GluR $\delta 2$ immunolabeling decreased, the length of the active zone became shorter in the order of normal, matched, and mismatched synapses. Furthermore, the dissociated portion of PSD at mismatched synapses showed a very low density of GluR $\delta 2 \mathrm{immu-}$ nogold particles such as free spines, whereas the density in the contacted portion at mismatched synapses was much higher and closer to that of matched synapses. The direct relationship between GluR $\delta 2$ density and synaptic contact suggests that postsynaptic GluR $\delta 2$ is essential for the maintenance of the presynaptic active zone and acts as the coordinator for presynaptic and postsynaptic differentiations. Thus, our results provide evidence for the postsynaptic control of the presynaptic active zone at mature synapses. Possibly, the postsynaptic GluR $\delta 2$ complex makes a physical linkage between the active zone and PSD to ensure the presynaptic and postsynaptic matching. There could be three potential mechanisms for this (supplemental Fig. 1, available at www.jneurosci.org as supplemental material). First, GluR $\delta 2$ may regulate the presynaptic active zone by direct interaction with an active zone component through its $\mathrm{N}$-terminal domain. Interestingly, studies using cultured hippocampal neurons showed that an extracellular domain of the AMPA receptor GluR2 subunit was important for induction of dendritic spines (Passafaro et al., 2003). In addition, analysis of mutant mice showed that the laminin $\alpha 4$ chain that can bind to presynaptic $\mathrm{Ca}^{2+}$ channels was required for the apposition of active zones and junctional folds at the neuromuscular junction (Patton et al., 2001). Second, GluR $\delta 2$ may regulate the presynaptic active zone through the interaction between a postsynaptic GluR $\delta 2$ interacting molecule and an active zone component. Interestingly, NMDA-type GluRs interact with Eph receptor tyrosine kinases capable of trans-synaptic signaling (Dalva et al., 2000). In Caenorhabditis elegans, ionotropic glutamate receptor GLR-1 is colocalized at the cell surface with SOL-1 (suppressor of lurcher-1) containing four extracellular $\beta$-barrel-forming domains known as CUB (complement subcomponents $\mathrm{C} 1 \mathrm{r} / \mathrm{C} 1 \mathrm{~s}$, Vegf, Bmp1) domains (Zheng et al., 2004). Third, GluR $\delta 2$ may regulate the presynaptic active zone more indirectly through a postsynaptic scaffold protein that binds to a molecule interacting with an active zone component. The C terminal of GluR $\delta 2$ associates with PSD-93 and PSD-95, which bind to the postsynaptic membrane protein neuroligin that is capable of interacting transsynaptically with presynaptic $\beta$-neurexin (Roche et al., 1999; Kim and Sheng, 2004; Uemura et al., 2004); however, there were no detectable alterations in structures at PF-PC synapses in PSD-93 mutant mice (McGee et al., 2001). Multiple scaffold proteins might be functionally redundant. Thus, elucidation of the GluR $\delta 2$ mechanism will provide a key for understanding the regulation of synaptic connections in the adult brain and the precise topological matching of presynaptic and postsynaptic specializations that are essential for efficient synaptic transmission.

The length of PSD was significantly shorter at matched synapses in mutant mice than at normal synapses in control mice according to the significant decrease in the density of GluR $\delta 2$ immunogold particles at matched synapses in mutant mice. A further decrease in GluR $\delta 2$ proteins, however, resulted in enlargement of PSD at mismatched synapses compared with matched synapses in mutant mice. Namely, a strong decrease in GluR $\delta 2$ proteins at the postsynaptic site of PF-PC synapses 


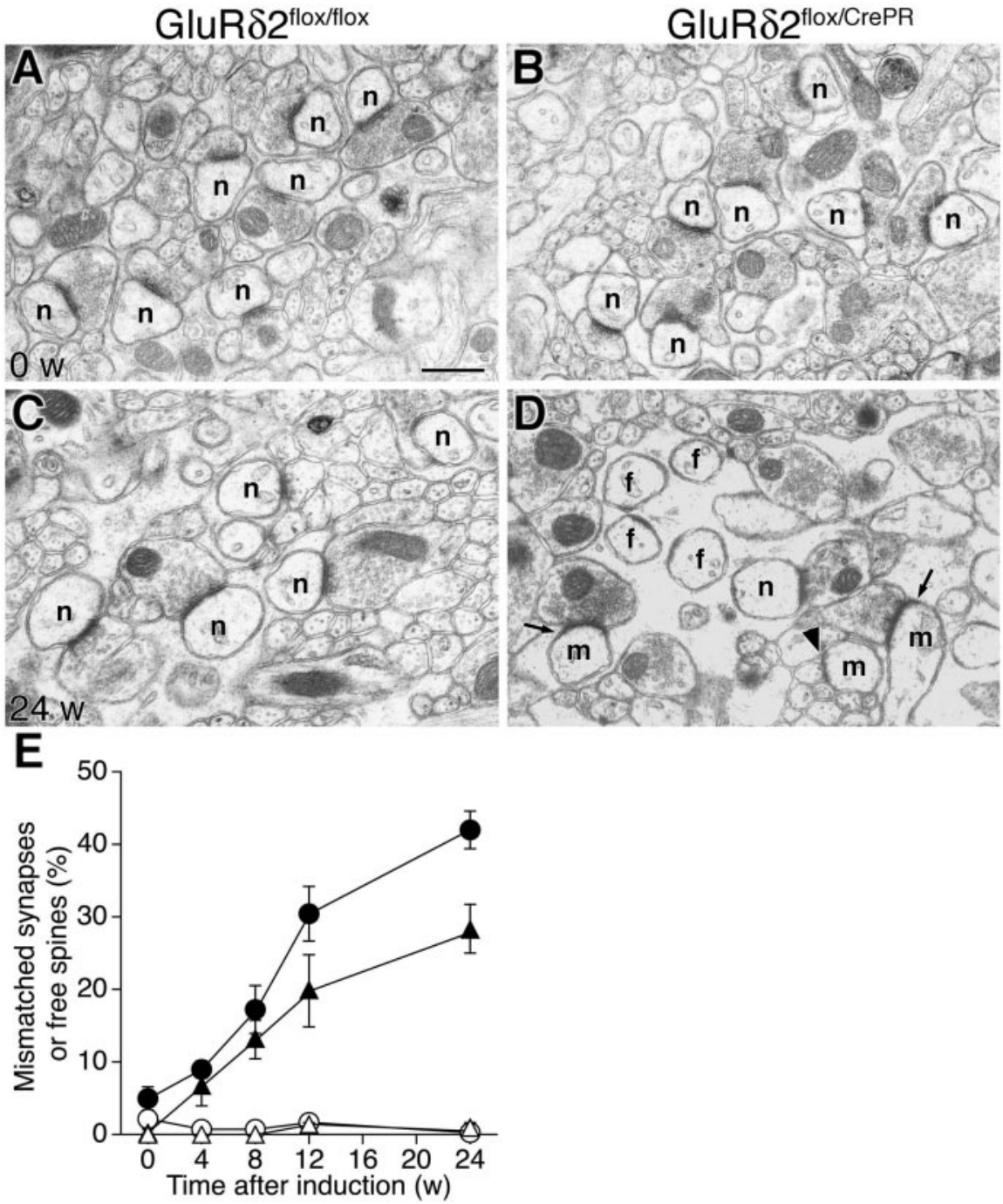

Figure 7. Temporal pattern of appearance of mismatched synapses and free spines in the cerebellum of GluR $\delta 2^{\text {flox/crePR }}$ mice after CrePR induction by RU-486 treatment. RU-486-treated GluR $\delta 2^{\text {flox fflox }}$ mice served as controls. $\boldsymbol{A}-\boldsymbol{D}$, Electron micrographs of

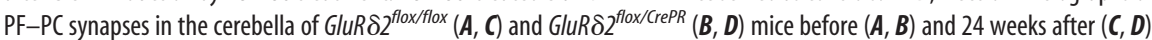
RU-486 treatment. Arrows indicate the mismatch between active zone and PSD at PF-PC synapses. An arrowhead indicates a rarely encountered abnormal spine, which possesses a PSD but contacts the nonterminal portion of PFs. f, Free spines; $m$, mismatched synapses; $n$, normal or matched synapses. Scale bar, $500 \mathrm{~nm}$. $\boldsymbol{E}$, Percentages of mismatched synapses (triangles) and

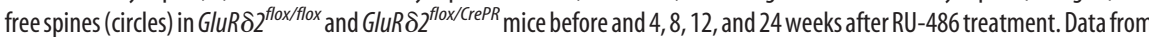

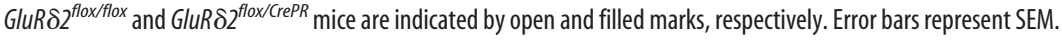

proteins, the PSD-93-labeling density was higher in the contacted portion of PSD than in the dissociated portion at mismatched synapses. On the other hand, there were no significant differences in the AMPA receptor-labeling density between the contacted and dissociated portions of PSD at mismatched synapses. In addition, AMPA receptor labeling was found in free spines without GluR $\delta 2$. The GluR $\delta 2$ linked distribution of PSD-93 and the relatively independent distribution of AMPA receptors at PSD suggest that GluR $\delta 2$ regulates the PSD organization at PF-PC synapses. Because ablation of PSD-93 alone appeared not to affect the synaptic structures (McGee et al., 2001), orchestration of multiple scaffold proteins by GluR $\delta 2$ may be essential. The decrease in GluR $\delta 2$ proteins at mismatched synapses thus caused the loosening of PSD organization, resulting in the enlargement of PSD. Loosening of PSD organization by GluR $\delta 2$ ablation may trigger the subsequent postsynaptic atrophy leading to free spines.

\section{References}

Araki K, Meguro H, Kushiya E, Takayama C, Inoue Y, Mishina M (1993) Selective expression of the glutamate receptor channel $\delta 2$ subunit in cerebellar Purkinje cells. Biochem Biophys Res Commun 197:1267-1276.

Bailey CH, Kandel ER (1993) Structural changes accompanying memory storage. Annu Rev Physiol 55:397-426.

Bloom FE, Aghajanian GK (1966) Cytochemistry of synapses: selective staining for electron microscopy. Science 154:1575-1577.

Dalva MB, Takasu MA, Lin MZ, Shamah SM, Hu L, Gale NW, Greenberg ME (2000) EphB receptors interact with NMDA receptors and regulate excitatory synapse formation. Cell 103:945-956.

Engert F, Bonhoeffer T (1999) Dendritic spine changes associated with hippocampal longterm synaptic plasticity. Nature 399:66-70.

Fukaya M, Watanabe M (2000) Improved immunohistochemical detection of postsynaptically located PSD-95/SAP90 protein family by protease section pretreatment: a study in the

shrunk the active zone but increased the PSD. Thus, the opposite effect of GluR $\delta 2$ ablation on the sizes of the active zone and PSD caused mismatching between the presynaptic and postsynaptic differentiations. The $\mathrm{C}$ terminal of GluR $\delta 2$ associates with the PDZ (PSD-95/Discs large/zona occludens-1) domain-containing proteins, including PSD-93, protein tyrosine phosphatase PTPMEG, and Delphilin (Roche et al., 1999; Hironaka et al., 2000; Miyagi et al., 2002). Recently, we found that GluR $\delta 2$ bound to the Shank family of scaffold proteins through an internal motif in the C-terminal region, and GluR $\delta 2-$ Shank complexes associated with the metabotropic GluR $1 \alpha$, the AMPA-type GluR, and the inositol 1,4,5-trisphosphate receptor, which are essential for cerebellar long-term depression (Uemura et al., 2004). Thus, it is reasonable to assume that GluR $\delta 2$ regulates the organization of PSD through the interaction with multiple postsynaptic scaffold proteins. In fact, PSD-93 protein density decreased in parallel with the decrease of GluR $\delta 2$ proteins at PSD. Similar to GluR $\delta 2$ adult mouse brain. J Comp Neurol 426:572-586.

Funabiki K, Mishina M, Hirano T (1995) Retarded vestibular compensation in mutant mice deficient in $\delta 2$ glutamate receptor subunit. NeuroReport 7:189-192.

Goda Y, Davis GW (2003) Mechanisms of synapse assembly and disassembly. Neuron 40:243-264.

Goodman CS, Shatz CJ (1993) Developmental mechanisms that generate precise patterns of neuronal connectivity. Cell [Suppl] 72:77-98.

Hashimoto K, Ichikawa R, Takechi H, Inoue Y, Aiba A, Sakimura K, Mishina M, Hashikawa T, Konnerth A, Watanabe M, Kano M (2001) Roles of glutamate receptor $\delta 2$ subunit (GluR $\delta 2)$ and metabotropic glutamate receptor subtype 1 (mGluR1) in climbing fiber synapse elimination during postnatal cerebellar development. J Neurosci 21:9701-9712.

Hering H, Sheng M (2001) Dendritic spines: structure, dynamics and regulation. Nat Rev Neurosci 2:880-888.

Hironaka K, Umemori H, Tezuka T, Mishina M, Yamamoto T (2000) The protein-tyrosine phosphatase PTPMEG interacts with glutamate receptor $\delta 2$ and $\epsilon$ subunits. J Biol Chem 275:16167-16173.

Ichikawa R, Miyazaki T, Kano M, Hashikawa T, Tatsumi H, Sakimura K, 
Mishina M, Inoue Y, Watanabe M (2002) Distal extension of climbing fiber territory and multiple innervation caused by aberrant wiring to adjacent spiny branchlets in cerebellar Purkinje cells lacking glutamate receptor $\delta 2$. J Neurosci 22:8487-8503.

Kashiwabuchi N, Ikeda K, Araki K, Hirano T, Shibuki K, Takayama C, Inoue Y, Kutsuwada T, Yagi T, Kang Y, Aizawa S, Mishina M (1995) Impairment of motor coordination, Purkinje cell synapse formation, and cerebellar long-term depression in GluR $\delta 2$ mutant mice. Cell 81:245-252.

Keinänen K, Wisden W, Sommer B, Werner P, Herb A, Verdoorn TA, Sakmann B, Seeburg PH (1990) A family of AMPA-selective glutamate receptors. Science 249:556-560.

Kim E, Sheng M (2004) PDZ domain proteins of synapses. Nat Rev Neurosci 5:771-781.

Kishimoto Y, Kawahara S, Suzuki M, Mori H, Mishina M, Kirino Y (2001) Classical eyeblink conditioning in glutamate receptor subunit $\delta 2$ mutant mice is impaired in the delay paradigm but not in the trace paradigm. Eur J Neurosci 13:1249-1253.

Kitayama K, Abe M, Kakizaki T, Honma D, Natsume R, Fukaya M, Watanabe M, Miyazaki J, Mishina M, Sakimura K (2001) Purkinje cell-specific and inducible gene recombination system generated from C57BL/6 mouse ES cells. Biochem Biophys Res Commun 281:1134-1140.

Köntgen F, Süss G, Stewart C, Steinmetz M, Bluethmann H (1993) Targeted disruption of the MHC class II Aa gene in C57BL/6 mice. Int Immunol 5:957-964.

Kurihara H, Hashimoto K, Kano M, Takayama C, Sakimura K, Mishina M, Inoue Y, Watanabe M (1997) Impaired parallel fiber-Purkinje cell synapse stabilization during cerebellar development of mutant mice lacking the glutamate receptor $\delta 2$ subunit. J Neurosci 17:9613-9623.

Lalouette A, Lohof A, Sotelo C, Guénet J-L, Mariani J (2001) Neurobiological effects of a null mutation depend on genetic context: comparison between two hotfoot alleles of the delta-2 ionotropic glutamate receptor. Neuroscience 105:443-455.

Lamprecht R, LeDoux J (2004) Structural plasticity and memory. Nat Rev Neurosci 5:45-54.

Landsend AS, Amiry-Moghaddam M, Matsubara A, Bergersen L, Usami S, Wenthold RJ, Ottersen OP (1997) Differential localization of $\delta$ glutamate receptors in the rat cerebellum: coexpression with AMPA receptors in parallel fiber-spine synapses and absence from climbing fiber-spine synapses. J Neurosci 17:834-842.

Lomeli H, Sprengel R, Laurie DJ, Köhr G, Herb A, Seeburg PH, Wisden W (1993) The rat delta- 1 and delta-2 subunits extend the excitatory amino acid receptor family. FEBS Lett 315:318-322.

Maletic-Savatic M, Malinow R, Svoboda K (1999) Rapid dendritic morphogenesis in CAl hippocampal dendrites induced by synaptic activity. Science 283:1923-1927.

Martin SJ, Grimwood PD, Morris RGM (2000) Synaptic plasticity and memory: an evaluation of the hypothesis. Annu Rev Neurosci 23:649-711.

McGee AW, Topinka JR, Hashimoto K, Petralia RS, Kakizawa S, Kauer FW, Aguilera-Moreno A, Wenthold RJ, Kano M, Bredt DS (2001) PSD-93 knock-out mice reveal that neuronal MAGUKs are not required for development or function of parallel fiber synapses in cerebellum. J Neurosci 21:3085-3091.

Mishina M (2003) Timing determines the neural substrates for eyeblink conditioning. Int Congr Ser 1250:473-486.

Miyagi Y, Yamashita T, Fukaya M, Sonoda T, Okuno T, Yamada K, Watanabe M, Nagashima Y, Aoki I, Okuda K, Mishina M, Kawamoto S (2002) Delphilin: a novel PDZ and formin homology domain-containing protein that synaptically colocalizes and interacts with glutamate receptor $\delta 2$ subunit. J Neurosci 22:803-814.

Miyazaki T, Hashimoto K, Shin H-S, Kano M, Watanabe M (2004) P/Qtype $\mathrm{Ca}^{2+}$ channel $\alpha 1 \mathrm{~A}$ regulates synaptic competition on developing cerebellar Purkinje cells. J Neurosci 24:1734-1743.

Nakagawa S, Watanabe M, Isobe T, Kondo H, Inoue Y (1998) Cytological compartmentalization in the staggerer cerebellum, as revealed by calbindin immunohistochemistry for Purkinje cells. J Comp Neurol 395:112-120.

Passafaro M, Nakagawa T, Sala C, Sheng M (2003) Induction of dendritic spines by an extracellular domain of AMPA receptor subunit GluR2. Nature 424:677-681.

Patton BL, Cunningham JM, Thyboll J, Kortesmaa J, Westerblad H, Edström
L, Tryggvason K, Sanes JR (2001) Properly formed but improperly localized synaptic specializations in the absence of laminin $\alpha 4$. Nat Neurosci 4:597-604.

Petralia RS, Sans N, Wang Y-X, Vissel B, Chang K, Noben-Trauth K, Heinemann SF, Wenthold RJ (2004) Loss of GluR2 $\alpha$-amino-3-hydroxy-5methyl-4-isoxazoleproprionic acid receptor subunit differentially affects remaining synaptic glutamate receptors in cerebellum and cochlear nuclei. Eur J Neurosci 19:2017-2029.

Plomin R (1990) The role of inheritance in behavior. Science 248:183-188.

Rampon C, Tang Y-P, Goodhouse J, Shimizu E, Kyin M, Tsien JZ (2000) Enrichment induces structural changes and recovery from nonspatial memory deficits in CA1 NMDAR1-knockout mice. Nat Neurosci 3:238-244.

Roche KW, Ly CD, Petralia RS, Wang Y-X, McGee AW, Bredt DS, Wenthold RJ (1999) Postsynaptic density- 93 interacts with the $\delta 2$ glutamate receptor subunit at parallel fiber synapses. J Neurosci 19:3926-3934.

Sans N, Vissel B, Petralia RS, Wang Y-X, Chang K, Royle GA, Wang C-Y, O'Gorman S, Heinemann SF, Wenthold RJ (2003) Aberrant formation of glutamate receptor complexes in hippocampal neurons of mice lacking the GluR2 AMPA receptor subunit. J Neurosci 23:9367-9373.

Scheiffele P (2003) Cell-cell signaling during synapse formation in the CNS. Annu Rev Neurosci 26:485-508.

Shimuta M, Yoshikawa M, Fukaya M, Watanabe M, Takeshima H, Manabe T (2001) Postsynaptic modulation of AMPA receptor-mediated synaptic responses and LTP by the type 3 ryanodine receptor. Mol Cell Neurosci 17:921-930.

Takayama C, Nakagawa S, Watanabe M, Mishina M, Inoue Y (1996) Developmental changes in expression and distribution of the glutamate receptor channel $\delta 2$ subunit according to the Purkinje cell maturation. Brain Res Dev Brain Res 92:147-155.

Takeuchi T, Nomura T, Tsujita M, Suzuki M, Fuse T, Mori H, Mishina M (2002) Flp recombinase transgenic mice of C57BL/6 strain for conditional gene targeting. Biochem Biophys Res Commun 293:953-957.

Taniguchi M, Yuasa S, Fujisawa H, Naruse I, Saga S, Mishina M, Yagi T (1997) Disruption of semaphorin III/D gene causes severe abnormality in peripheral nerve projection. Neuron 19:519-530.

Tsien JZ, Huerta PT, Tonegawa S (1996) The essential role of hippocampal CA1 NMDA receptor-dependent synaptic plasticity in spatial memory. Cell 87:1327-1338.

Tsujita M, Mori H, Watanabe M, Suzuki M, Miyazaki J, Mishina M (1999) Cerebellar granule cell-specific and inducible expression of Cre recombinase in the mouse. J Neurosci 19:10318-10323.

Uemura T, Mori H, Mishina M (2004) Direct interaction of GluR $\delta 2$ with Shank scaffold proteins in cerebellar Purkinje cells. Mol Cell Neurosci 26:330-341.

Watanabe M, Inoue Y, Sakimura K, Mishina M (1993) Distinct distributions of five $N$-methyl-D-aspartate receptor channel subunit mRNAs in the forebrain. J Comp Neurol 338:377-390.

Watanabe M, Fukaya M, Sakimura K, Manabe T, Mishina M, Inoue Y (1998) Selective scarcity of NMDA receptor channel subunits in the stratum lucidum (mossy fibre-recipient layer) of the mouse hippocampal CA3 subfield. Eur J Neurosci 10:478-487.

Wolfer DP, Müller U, Stagliar M, Lipp H-P (1997) Assessing the effects of the $129 / \mathrm{Sv}$ genetic background on swimming navigation learning in transgenic mutants: a study using mice with a modified $\beta$-amyloid precursor protein gene. Brain Res 771:1-13.

Yamada K, Fukaya M, Shimizu H, Sakimura K, Watanabe M (2001) NMDA receptor subunits GluR $\epsilon 1$, GluR $\epsilon 3$ and GluR $\zeta 1$ are enriched at the mossy fibre-granule cell synapse in the adult mouse cerebellum. Eur J Neurosci 13:2025-2036.

Yamazaki M, Araki K, Shibata A, Mishina M (1992) Molecular cloning of a cDNA encoding a novel member of the mouse glutamate receptor channel family. Biochem Biophys Res Commun 183:886-892.

Zhao H-M, Wenthold RJ, Petralia RS (1998) Glutamate receptor targeting to synaptic populations on Purkinje cells is developmentally regulated. J Neurosci 18:5517-5528.

Zheng Y, Mellem JE, Brockie PJ, Madsen DM, Maricq AV (2004) SOL-1 is a CUB-domain protein required for GLR-1 glutamate receptor function in C. elegans. Nature 427:451-457. 